Marian Walerian NowaK

\title{
THE PROBLEM OF SOCIAL ENGAGEMENT OF A CHILD WITHIN THE FAMILY AND BY THE FAMILY IN THE VIEWS OF SELECTED REPRESENTATIVES OF SOCIAL PEDAGOGY ${ }^{1}$
}

\section{USPOŁECZNIENIE DZIECKA W RODZINIE I PRZEZ RODZINĘ W POGLĄDACH WYBRANYCH PRZEDSTAWICIELI PEDAGOGIKI SPOŁECZNEJ}

\begin{abstract}
This article deals with the problem of the social engagement of a child within the family and by the family. The category of social engagement itself, although less common nowadays, has its own meaning and can be connected with such categories as socialisation, upbringing - especially upbringing, but also adaptation, support or teaching and learning - especially so-called social learning. Teresa Kukołowicz links the process of upbringing with social engagement, and indicates the family as the scenario of their particular connection. The activity of the social engagement of the child within the family requires a clear formulation of its purpose, which, as in the other categories mentioned above (especially in upbringing), is connected with socialisation and personalisation. However, are we really dealing today with aspirations to socially engage the child? Is the family supported in the process of social engagement of the child? Why is the family so important, and why is its role so crucial in the process of the child's social engagement? These are the issues which are the focus of attention in this article.
\end{abstract}


Socialisation, usually considered as learning values and social norms, as preparation to perform social roles, or as forming conscience, today is reduced to a mere adaptation - which also comes with manifest detriment to the process of social engagement. This process for the child within the family should therefore adopt an explicit correlation with the common good, in connection with which the family is the most-appropriate scenario, because of the situations and interpersonal relationships which arise within it, as is particularly evident when comparing the family, for example, with the children's home. This latter scenario does not exclude the possibility, or the need, to support the family in its involvement in the social engagement the child, not only by a closer or even more-distant family, but also by institutions and communities able to contribute their own educational environments, and their own correlation to the common good. Such cooperation points to a partnership in the broadest sense of the word, in which authentic "dialogue" is a particularly important means.

KEYWORDS: social engagement, socialisation, personalisation, family, institutions, educational situations, common good

The category of "social engagement", although it is less-and-less common today, has its meaning in social sciences, including pedagogy, and may be connected with other pedagogical categories and related disciplines associated with the child's development, and its conditions and circumstances. Following the description by Teresa Kukołowicz, who links the process of upbringing with social engagement, and points to the family as the scenario of the child's special connection, this article takes up this specific fact, starting from the search for terminological explanations related to "social engagement", and especially to the social engagement of the child within the family (Kukołowicz, 1978). As every human activity is purposeful, it is also necessary to search for the purpose for the socially engaging activity of the family, going further than the often-cited personalisation and socialisation of the pupil. The question posed in this article is: How does the social engagement of the child take place within the family and by the family, and what is the essence and specificity of such influence by the family on the child?

In order to obtain the purpose of this article and to answer to the given question, several issues showing the relation between the social engagement of the child and the role of family will be presented. The considerations in question were based on works of the chosen representatives who deal with 
this subject and who put special attention on link between social engagement, uprising, family and the common good.

By pointing to the common good, and to the family, as well as to possible upbringing situations and interpersonal relations within it, an answer to these questions can be found, and their verification can be done by comparative reference to, for example, children's homes, or to the role of other educational-care facilities for children. Of course, the family should receive adequate support in its activity of the social engagement of the child, not only from the family, whether close or more distant, but also from institutions and the community in general, which do indeed contribute their own educational situations and their own relationship to the common good (but precisely by doing so make the social engagement of the child even-more complete and original), and which through a broadly defined partnership and genuine "dialogue" should seek the opportunities to provide such support.

\section{THE SOCIAL ENGAGEMENT OF A CHILD WITHIN THE FAMILY AS AN OBJECT OF PEDAGOGICAL RESEARCH}

The issue of the social engagement of the child within the family and by the family, although it is included in the category of the upbringing influences of the family, and is the object of interest of family pedagogy in particular, it also enters the scope of interest by social pedagogy and other disciplines, which take up issues related to such categories as socialisation, upbringing - especially social upbringing, but one can also see the connections of this activity with adaptation, the support of pupils, or also teaching and learning - especially so-called social learning. These are very-important categories, closely interrelated and requiring reflection, not only within a single discipline of knowledge or sub-discipline, but also indicating the necessity of an interdisciplinary approach.

This kind of interrelation, especially between the process of upbringing and the social engagement we are interested in, is clearly attested to by, among others, Teresa Kukołowicz (1925-2014), when writing: "The process of upbringing, and thus of social engagement, is realised thanks to situations 
as sets of stimuli and reactions to them" (1972, p. 185). As a matter of fact, each of these notions in its intentionality points to the pursuit of the social engagement of the pupil.

However, are we really dealing today with aspirations to socially engage the child? Is the family supported in the process of the social engagement of the child? Why is the family so important, and why is its role so crucial in the process of the child's social engagement? These are issues which are the focus of attention in this article.

Even a simple observation of the basic trends we are dealing with today rather indicates actions either completely opposite to the socially engaging role of the family, or attempts not only to replace this activity by the activity of institutions, e.g. children's homes, but also by the mere adaptation of the child or the pupil - and therefore to transform it completely and give it a completely different character. Let us therefore first turn to the explanation of the actual category of "social engagement" which interests us.

Dictionary explanations of the term "social engagement" contained, for example, in Mały słownik języka polskiego PWN [A small PWN dictionary of Polish] (Skorupka et al., 1969, p. 868), or Słownik języka polskiego PWN [A PWN dictionary of Polish] (sjp.pwn.pl), clearly indicate that social engagement is understood in two senses

- as making someone socially adept, conforming to the demands of society, or

- making something into social, State, or cooperative property.

The cited dictionary explanations also point to the term to socially engage in both perfective and imperfective forms, and according to these two explanations given above, they also speak either of becoming socially adept, or (with reference to the objective reality) of becoming the property of society, or of some social group.

In pedagogy we are especially interested in the first explanation, emphasising the subject's activity own in the social sphere. This aspect is also emphasised by the above-mentioned categories related to social engagement, especially socialisation and upbringing, and to a lesser extent by adaptation, which in excessively extreme approaches seems to be more related to the dictionary explanations of social engagement in the latter (more-passive) meaning, as 
applied to objects and objective reality, but unfortunately applying it to persons, often to children and adolescents, is sometimes attempted.

Of course, this raises a fundamental question: are social engagement (just like socialisation), support, or upbringing, for a purpose? And, in relation to this, we usually ask for what purpose? Or why do we take such actions? These actions cannot be devoid of purpose. We rightly ask, as the process of social engagement is also linked by T. Kukołowicz with "the possibility of contact with the common good" (1972, p. 185). It is only in relation to a certain purpose that we can cite methods, as well as establish principles of behaviour, among which, above all, the principle of respect for the dignity of the child and for others becomes important in interpersonal relations (Nowak, 2008, pp. 352 et seq.).

In order to uphold the principle of respect for the dignity of the pupil in activities socially engaging young people, as well as in socialising or educating interventions, it is demonstrated that there should be a specific balance between the two basic categories, and at the same time goals, which are socialisation and personalisation.

These aims for education were explicitly cited, among others, by the Commission of National Education (1872), established in 1773, in whose Acts of 1783 we can find a concise formulation that a pupil should be brought up in such a way that "he will be well and [others] will be well with him". Also, in connection with social engagement, we can point to personalisation (as part of the search for the good of the child by making him or her active and supporting a child's personal development) and socialisation (as part of the orientation of the individual to the social dimension of that individual's life) - as the basic aim (Kukołowicz, 1978, p. 27).

The enormous role of the Commission of National Education in the area of describing the principles of education related to social involvement has been indicated by many authors, including K. Bartnicka. It is noted that the basis of upbringing and education was to be the equality of all children, regardless of their social status (Bartnicka, 2014, p. 114). This author also points to the important aspects of education in the Commission of National Education's schools, which is patriotic education (Bartnicka, 1998).

Such is the purpose of the explanation of the category "the social engagement of the child", as presented above, and therefore let us turn our attention 
to the understanding of socialisation as well as personalisation on the grounds of pedagogy in relation to this category.

Social engagement is the guiding principle for all initiatives related to the support of the pupil, the emigrant, or the person in general in his/her specific life and social situations. Social engagement often requires support for the pupil within the context of his/her immersion into social life. Teresa Kukołowicz explicitly points out, in relation to social engagement, "The importance of coming into contact with the principles on which the realisation of the common good depends cannot be overlooked either [...]" (1972, p. 185).

Certain principles are essential for the realisation of the common good, and they include social love directed towards the good of people, and the common good, and uniting everyone around the good of the community. Another principle is justice, which involves giving to everyone what is due to them, and especially the protection of human rights, among them the right to development, care, and assistance, especially the application of social justice, also legal justice (Kukołowicz, 1972, p. 199).

Social engagement, therefore, in order not to also become, in relation to human beings, something that will more reflect the latter dictionary meaning - objective (in the sense of merely making something social), requires respect for certain principles, including, in particular, respect for human dignity (Nowak, 2017, pp. 299-308).

Therefore, we talk about the need (and sometimes in respect of upbringing about the principle of respecting the dignity of the pupil and the educator), and especially to maintain the subjective character of interpersonal relations (Nowak, 2008, p. 352). In the processes of a child's social engagement, socialisation, or upbringing, both the one who acts to socially engage others and those who are subject to such activities should constantly be subjects of these actions (Nowak, 2009, pp. 11-23).

Some help in understanding social engagement and its purposefulness can be provided by referring to the process of socialisation, in which it is indicated that it might be in the scope of its meaning encompass activities related to:

1. the transmission of values and social norms (resulting in the acquisition of the ability to distinguish values from what is not a value, to 
choose one or another value, and to understand them in the context of social norms),

2. preparation to fulfil social roles (i.e. learning and teaching to fulfil social roles, and entering into regulated social life), as a certain system determining the interdependence of roles,

3. the formation of conscience (capable, in relation to concrete situations, of acting and making decisions guided by one's own moral sensitivity and universal moral values) (Nowak, 1999, pp. 245-248).

Nowadays, however, such an understanding of socialisation is disappearing, and it is often even identified exclusively with adaptation processes, just as it is in relation to the social dimension of teaching and upbringing (Ibid.; Nowak, 1992).

There is no shortage of voices of sociologists who, as Rudolf Tartler (1921 1964) would even like to make adaptation a goal in itself. The aforementioned author even states "the goal of adaptation is precisely constant, permanent, adaptation” (1955, p. 338). Karl Bednarik (1915 - 2001), goes even further in this thinking, pointing to "adaptation to adaptation", in which any kind of goal in the present civilisation of progress and learning, "is the goal of a certain continuously renewed capacity to adapt" (1954, p. 21).

This chorus of voices is joined by Zygmunt Bauman (1925 - 2017), whose view is that everything solid has evaporated (Bauman, 2008, p. 183). According to Zygmunt Bauman „In the context of the pluralism of principles (and our times are times of pluralism) moral choices (and the moral conscience which follows them) appear as fundamentally and ineffaceably ambivalent" (1984, p. 13).

It is not difficult to see that Bauman, forgetting, or perhaps without any greater awareness of, the fact that ethics never expects the universal recognition of universally formulated moral norms, evidently mixes the universal validity of certain moral norms in ethics with their universal recognition (Hołub, 2013, p. 11).

In turn, based on his sociological description of "liquid postmodernity", Bauman formulates praxeological norms, which Karol Wojtyla called precisely and only norms of adaptation, which are far from any ethical norms, just as is the case with other representatives of postmodernity, who, even when writing about norms, indicate only certain "norms of adaptation" (as is the case, for example, in Michael Foucault's "ethics of the care of the self" (1994), or in Richard Rorty's 
"ethics" (1996, p. 132), who draws on Darwin's theory, i.e. on the consequences of biology, therefore one of the exact sciences (Rorty, 1997), and in this area tries to "combine" in fact, and only in some norms of social adaptation.

However, this would only be an adaptation, and would have nothing to do with the social engagement or education of a person. This kind of pedagogy of adaptation (or also socialisation understood in an oversimplified sense and reduced to adaptation), if it were based solely on a biological (or on any of the exact sciences) understanding of the meaning of adaptation, capitulates before reality and betrays it. Upbringing, including social support, or even socialisation, which focuses on a given set of relations and adapt a young person to them, and does not release the need to transform them in the sense of responsibility towards universal principles and norms, are always doomed to lose their meaning and significance, as they aim at treating people as objects and not as subjects.

The case is similar for the issue of personalisation, which is stated as the second basic aim of the social-engagement actions directed at a pupil. If it were to describe the purposefulness of such actions, it should be related to the liberation of the social "I" of the human being - for a person has both an individual and a social nature.

The human person adapts to the world in which he or she lives, but always as a subject, responding creatively and originally to the needs of the environment (external) and one's own (internal, personal) - and this in a dynamic and active way. Only such a state of affairs leads - as Gordon Willard Allport (1897-1957) maintained - to "the development in oneself of unique ways of adapting to the environment and mastering it: it is these ways that create personality" (1988, p. 53). This can never be understood as self-realisation, but should precisely be linked to social engagement. As Bogdan Suchodolski clearly and repeatedly pointed out, one's own self-realisation can never be the aim of upbringing, or one's own development, because a person's destiny is the social life into which the person will enter, and which that person will continue to co-create with others with its own involvement.

The task of the educator is not to make the child fit into the world, but, as Aristotle (384-322 BC) already wanted to arouse in him a desire for a more- $h u$ man existence, a motivation to live a truly human life (Nowak, 2013, p. 268). These processes, and the correct reading of their purposefulness, as well as the 
application of the appropriate principles or criteria of action, require particular attention in the first developmental periods of the child, which usually, and most favourably, take place within the family. It is the family in which, in the most-basic and natural way, implements the process of the social engagement of the child, as well as upbringing and teaching, aimed at the objectives which we have defined as socialisation and personalisation.

It is therefore not surprising that in the works of J.H. Pestalozzi (1746 - 1827), who wanted to properly mould teachers, we find model references to the relationship between parents and children in the family, and especially to the style of this relationship as manifested by mothers (Pestalozzi, 1955).

\section{THE PROCESS OF UPBRINGING THE CHILD WITHIN THE FAMILY THROUGH CLOSE INTERPERSONAL RELATIONSHIPS, AND THE FULL DEVELOPMENT OF THE PERSON AND ORIENTATION TOWARDS THE COMMON GOOD}

The family is the primary educational environment which supports the educational development of the child through ordinary everyday life, but this is also through the experience of common values through religious, national, local, and global festivals and celebrations.

In the teachings of John Paul II, there is the conviction of the decisive importance of the permanent bonds of spouses-parents in the upbringing of the child. Raising a child in the family takes place mainly through the daily building of a community based on mutual service. However, this requires an adequate anthropological concept of the child and the family, capable of overcoming both the optimistic and the pessimistic approaches of modern and contemporary concepts of education. 


\section{FORMS OF EXPERIENCING THE COMMON GOOD IN THE PROCESSES OF SOCIAL ENGAGEMENT}

The process of upbringing is at the same time a process of the social engagement of the young person - both are realised thanks to situations involving sets of stimuli and human reactions to them. In pedagogy it is propounded that the situation constituting the basis and surroundings of the processes of upbringing and teaching, or social engagement, is - according to Stefan Kunowski (1909-1977) - "a system of stimuli, factors, and influences" which bring about the development of a human being. They take effect both in the pupil him or herself, and in educational situations, also manifesting themselves also through the actions of educators. According to Kunowski, they therefore have different origins and produce different effects in the process of upbringing (Kunowski, 1993, p. 262; Nowak 1999, pp. 528-529).

Situations shape people through experience. It is in them and through them that the pupil acquires life experience. Therefore, it can be said that it is the situations which shape the person. For this reason, many pedagogues, among them Maria Montessori (1870 - 1952), Ludwika Jeleńska (1885 - 1961), and St. Urszula Ledóchowska (1865-1939), pointed to the clear need to organise situations in order to achieve specific aims of upbringing.

Especially considering social engagement, educational situations should create the opportunity of contact with the common good. According to Teresa Kukołowicz, social engagement should manifest itself as a certain ideal - the goal of the community, which is pursued, but also as a commonly pursued good (Kukołowicz, 1978, pp. 26-29).

Another form of this good should be its manifestation as the perfection of the person, i.e. the internal common good (Kukołowicz, 1968; Kondziela, 1968; J. Krucina, 1967). Focusing on the problem of the social engagement of the child within the family and by the family, it is possible to bring out the specificity of these situations by comparing the family with institutions, and with situations which occur outside the family, for example in children's homes.

However, this problem requires a more-profound analysis by referring in particular to the anthropological and legal basis of the social engagement of the child within the family. Since the problem of the social engagement of 
the child within the family is the object of interest of social philosophy and anthropology, as well as the social sciences and legal sciences, let us start from the anthropological and legal foundations of the social engagement of the child within the family, within which it is indicated, among other things, that:

1. A person has both an individual and a social nature, and therefore requires the influence of the family to shape his or her individual character and of the community to shape his or her social dimension of functioning and life.

2. Individual upbringing emphasises the value of the individual, the uniqueness of the human person, and tries to support the development of the individual person as fully as possible. This approach to upbringing accentuates the personal, individual existence, the uniqueness of the person - the proper place within the family.

3. "Social education", on the other hand, acknowledges the person as a "social being" (zoon politikon).

A certain regularity is noted in this regard, and there are clear consequences of such distinctions, even in legal documents, which can be expressed in this way.

1. If in anthropological justifications we begin to emphasise independence, the value of the individual human being, his or her individuality, the emphasis thus shifts to "family education". The child's right to full development and individualisation is asserted, emphasising that this is optimally guaranteed by the family.

2. If, on the other hand, emphasis is placed on the fact that a person exists as a social being, with the accent on the social and collectivist (State) aspect of upbringing, then even the model of individual and family upbringing is judged from these positions as outdated, congruent with the bourgeois and traditionalist community (Nowak, 1993, pp. 8 - 27).

Let us refer to selected concrete examples of this state of affairs in the basic documents which are, for States, their "Constitutions".

Example 1: The 1952 Constitution of the Polish People's Republic. In Article $67 \$ 1$ we read, inter alia, "Marriage and the family are under the protection and guardianship of the Polish People's Republic". 
In turn, in Article 68, the quoted document emphasises "The Polish People's Republic surrounds the upbringing of young people with particular care, and provides them with the widest opportunities for development".

We see in these formulations the priority role assigned to the State - without any statement about the rights of the family to raise its children. According to the 1952 Constitution of the Polish People's Republic, the person was seen as a social being (a collective) and as such falling under a historical process (the person is its object). The basis for such statements - the "social concept of the person";

Example 2: In the Basic Law for the Federal Republic of Germany (Grundgesetz), as early as in the introductory part, in Article $6 \$ 2$ we read "The care and upbringing of children are among the natural rights and at the same time the most-fundamental duties of parents". This right is admittedly restricted by the edict "This activity of the parents shall be supervised by the State”. (Art. $6 \S 3$ ), which can intervene if those with a right to bring up children fail, or if for any reason the children suffer harm.

The right of upbringing is in the first place vested in the family, and it is called the "natural right of parents", and only in the second place can social institutions be involved. The German version reads "Pflege und Erziehung der Kinder sind das natürliche Recht der Eltern und die zuvörderst ihnen obliegende Pflicht”. (Grundgesetz der Bundesrepublik Deutschland, 1972, Article $6 \$ 2$ ). The person is hier subject.

\section{THE EXPERIENCING OF THE COMMON GOOD IN SITUATIONS OF FAMILY LIFE}

The child should experience and encounter a specific common good of a concrete community, living in a certain place and time, which at the same time develops and changes.

Let us begin by drawing attention to the ambiguity of the term "experience". Experience itself has both an object side (experience of something) and a subject side (experience of someone). It is an epistemological, gnoseological, and methodological category. 
As Kazimierz Twardowski claimed (and Kazimierz Sośnicki developed it in the field of pedagogy), experience can be understood as an activity of cognition, or as a product or result of this activity, termed information or knowledge. Experience can also be understood as a way/method of cognition. It is worth mentioning that the first important distinctions in this regard were made by John Locke (1632 - 1704) in his work dedicated to human understanding, distinguishing two types of experience - external experience (sensual, e.g. through sight) and internal experience (experience of oneself) - through reflection (Nowak, 2010, pp. 168-182).

In pedagogy, experience, understood as an activity, is sometimes attributed to the educator or the pupil who are the subjects of this experience. It is also possible to discuss the educational environment (the object of experience in terms of the pedagogy of the subject), as a space in which the experience takes place.

Experience can also be understood in terms of a product, and attributed to the pupil or the educator. The experience of the pupil is what the pupil acquires in the process of education (competences, skills, knowledge, etc.). The experience of the educator, also referred to as the pedagogical experience (of teachers) is a type of social experience, and can be the basis for pedeutology or andragogy (Nowak, 2010, pp. 168-182).

In the process of the social engagement of the child within the family, the experience of the upbringing related to the common good is of particular importance. The child's contact with the principles or criteria of the realisation of this common good seems to be particularly important, which can include social justice and love, as well as the need for power (Kukołowicz, 1978).

The aspiration of the family is to ensure the full development and well-being of its members. This aspiration meets the criterion of the common good.

From the point of view of social sciences, especially sociology, the family is seen as a group, and this group is usually formed when people concentrate around a goal which they pursue together.

Such an aim is the common good of the group. The common good is realised in the family through the functions it fulfils, which, according to Szczepański (1913 - 2004), are the primary functions of the family: procreation, nurturing, 
education and upbringing, and security. On the other hand, he listed the following functions as secondary - economic, stratification, care, recreational, religious, and integration functions (J. Szczepański, 1970, pp. 258 et seq.).

In the above-presented distinctions into the personal (individual) and institutional (social) character of the caring and upbringing activity of the family, a very-clear contribution was made by Franciszek Adamski, who divided the functions of the family from the point of view of permanence and changeability, distinguishing two groups - primary (basic) and secondary. He classified as the primary functions of the family procreation, socialisation, bonds of love.

Viewing family functions from two perspectives: the family as a group and a social institution, he divided these functions into

- institutional (procreative, economic, caring, socialisation, stratification)

- personal - marital, parental, fraternal (Adamski, 2002, pp. 36-37).

In turn, Nathan W. Ackerman (1908 - 1971), speaking about the functions of the family, points to "providing food, a roof over the head and other necessary conditions to stay alive, providing opportunities for social coexistence as a basis for the formation and development of a sense of connection, and providing the necessary conditions for the shaping of one's own individual personality" (Ackerman, 1959, p. 16).

The fulfilment of these functions contributes to the development not only of the children but also of the parents, increasing their integration into the community, their care for each other, taking on tasks for the whole community, and also enriching them with new experiences. In fact, children establish the spouses as parents, father or mother, and their parents as grandparents or great-grandparents, just as the father or mother in the initial period of life give a kind of credit for the quality of the child's identity during adolescence, which was very-clearly and deeply shown by Karol Wojtyła in his drama dated 1964 under the title Promieniowanie ojcostwa [The Radiance of Fatherhood] (Wojtyła, 1979, pp. 228-258).

In this regard, Natalia Han-Ilgiewicz (1895 - 1978) pointed to the reciprocity of influences which we deal with in the family. For in the exercising of the functions of motherhood and fatherhood, both parents receive certain benefits, as do the children. In the case of parents, the fulfilment of the functions of fatherhood and motherhood leads to, in particular, a decrease in egotism, 
with a simultaneous increase in a more matter-of-fact attitude. The exercise of these functions therefore serves all the members of the family, also with regard to the common good, which takes real shape with the fulfilment of various functions by the family, giving the child the possibility of multiple rich experiences throughout the stay within the family home (Han-Ilgiewicz, 1970, p. 7; Kukołowicz, 1972, p. 186).

The common good of the family therefore takes real shape especially through its fulfilment of various functions. The common good of the family also has an external expression of its common good, which is the subculture of the family. It arises as the family pursues its goals in accordance with certain norms and values it has adopted. According to Jan Szczepański, references to family members and strangers, to issues and goals, shared views, etc., give the general shape to the subculture of the group, which manifests itself in the situations of family life experienced by the family. All these references are internalised by the child living within the family, and in this way the child forms ideas about the world and people, about the family and its goals, as well as about what the common good is for the family (Szczepański, 1970, pp. 303-305).

\section{THE DYNAMICS AND FACETS OF THE COMMON GOOD WITHIN THE FAMILY}

In the family, the child encounters diverse facets of the common good, which at the outset are revealed by the ordinary everydayness of family life (Kukołowicz, 1998, pp. 207-212) and the realism of the experienced situations. The economic aspect of the common good includes the home and its furnishings, appliances, equipment, personal belongings, savings, the daily use of numerous goods of this kind, the expenditures budget, and also the time budget and the working out of the so-called "norm of performance of the common good, i.e. the specific common good corresponding to a given family at a given stage of development". (Kukołowicz, 1972, p. 189).

The common good of the family arises as a result of the internal interdependence of the subsystems which are in its structure, and among which we can include marriage, which also has a common good in the pursuit of its 
goal, which is love and the community of life (Lacroix, 1958, p. 176). This is not only in line with the Catholic doctrine on the family, but also sociology defines marriage as a group in which the partners seek love, happiness, and mutual companionship. This common good which is the marital bond does not cease to exist when, with the appearance of children, the family is created, becoming a condition for the continuation of the marriage and the proper development of the family. Alongside the good of the marriage and the spouses, the good of the children, the good of the mother and the child, and the good of the father and the child, the good of women and the good of men, arise.

With the arrival of children, the goods of the various subsystems which make up the important dimension of the common good - the good of the family - continue to grow and multiply. The good of siblings, brothers and sisters, boys and girls, younger and older children, arises. The common good of the family encompasses all these goods, constituting a synthesis of them, and thus the result of linking the individual systems and providing the basis for the formation of a certain whole. Subsequently, the joint solving of problems and difficulties which arise, the overcoming of conflicts within and outside the marriage, the expression of emotions, and the formation of friendships, are forms of the common good, in which the children participate, and towards which they adopt certain attitudes.

Thanks to these experiences, the members of the family become capable of meeting and participating in the common good of different groups, and the experiences undergone correspond to commonly occurring groups and their selection, becoming universal, and leading to their transfer to adult life.

The common good within the family has a dynamic nature, manifesting itself in its expansion and enrichment, or, conversely, its narrowing in aims, as well as values and in economic good. Thus, the good of the family changes with the age of family members, especially with the size of the family - the larger the family and more complex (e.g. several generations), the more possible arrangements of interpersonal relations (Crisp, Turner, 2009).

The good of the family is also conditioned by the economic situation of the family, by the reading of books and the press, by the use of media and electronic 
information carriers, by e.g. making music at home or arts and crafts, and finally by engaging in sports or tourism, etc. The status of the family's common good is also influenced by developmental trends in the modern world, the existing and future-oriented standard of living and lifestyle, culture and religion, the choice of fields of study and interests, also by professional traditions and family customs, as well as by the memory of ancestors, in particular the cultivation of the memory of the family's ancestors and their involvement in important political, social, national or religious events. All this influences life ambitions and, within the framework of social learning, triggers specific aspirations for imitation. Jan Szczepański, taking into account the above-mentioned aspects, stated "the family constitutes a mechanism of social inheritance" (J. Szczepański, 1970, pp. 304 et seq.).

All these facts are experienced by the child in the context of the entirety of the needs of the family as a community, as well as the needs, likes, and talents of its individual members. In the context of other people who are loved and close to the child, the child's own abilities are recognised and compared to the abilities of others, and a sense of community and at the same time the recognition of the reality of his or her own contribution is formed (Schaffer, 2005, pp. 105-144).

It is also impossible to ignore the attention paid to the values present in family life, which make it possible to maintain cultural continuity through the transmission of language, customs, behavioural patterns, worldview, and religion.

\section{THE COMMON GOOD AND ITS IMPLEMENTATION IN SITUATIONS OF UPBRINGING WITHIN THE FAMILY AND IN CHILDREN'S HOMES, AND OTHER INSTITUTIONS AND SUPPORT GROUPS}

The upbringing of the child also takes place in institutions other than the family: in nurseries, kindergartens, schools, sports clubs, and also in children's homes, etc. Comparing the course of the social engagement of the child within the family and in other institutions allows the specificity and particular quality of this process within the family to be highlighted even more clearly. 
First of all, it is worth pointing out that institutions of this kind which support the educational activity of the family enter the sphere of the family, just as families and groups of friends and colleagues enter the family, not to mention e.g. nannies, babysitters, and every single person in general. All of them are already characterised by specific educational situations in which they function and with whose specific "stigma" they enter the process of social engagement of the child carried out in a concrete family, and this in the entirety of his childhood and life (Kukołowicz, 1972, p. 200).

Jan Szczepański rightly notes that each family creates "its own cultural environment within the general framework of a broader community (nation, Church, State), and this environment shapes the personality of children" (Szczepański, 1970, pp. 163 et seq.). The family transmits language, customs, and cultural and religious values, thus ensuring the continuity of cultural heritage, etc. All this also demonstrates its great role in the process of the social engagement of the child - and in the sense explained at the beginning of the article - in the objective meaning.

However, one cannot disregard all these external factors and circumstances created by specific individuals and their groups, which also contribute to the creation of unique educational situations in the environment of a particular family, but there are also institutions which support the process of the social engagement of the child within the family, such as kindergartens, children's gardens, and nurseries, which enter into this process with their own intentionality and understanding of the common good. Among these institutions, where the child spends only a certain part of the day, the children's home is distinguished in particular, as it is a "total institution", covering the entire days and nights of the child's life. In this respect, although there is a certain similarity between the children's home and the family home - in the children's home, as within the family, the child spends the whole day - it is also a group, but each time we have specific educational situations, which are completely different.

Let us therefore also compare life and the process of the social engagement of the child within the family with life in a children's home - selecting at least certain aspects and relating them to the common good. Mere reflection and life experience suggest that there are fundamental differences in the specific 
educational situations which distinguish the children's home from the family, even though sometimes we also can note similar aspects

1. The children's home, like the family, is a social group, but nevertheless more institutionalised, and, as a social group, different

2. The family is a primary group, the children's home a secondary group it is established with specific intentions and a worked-out activity programme

3. Secondary groups are created for the realisation of a specific purpose, and the family being created is a community concerned about the good of its members, among whom we can speak of direct relations - "from heart to heart"

4. The children's home does have some good of its own, but this good is not the object of its pupils' own actions, but something guaranteed to them, or provided by persons specially appointed for this purpose, etc.

5. The common good in educational situations in children's homes and other institutions, due to institutionalisation, is less objective, and always more subjective and distant from the needs, expectations, and aspirations of each of the wards

6. In the children's home, the "executive norm of the common good" is poorly represented, which in families is worked out, and more-so than in children's homes it is related to the specific stage of development of the family

7. The realisation of the tasks of the children's home is guaranteed by the management with the presence of power and organisational structures (these structures are even whole subsystems: pupil - educator (exchanging educators), pupil - administration, pupil - other pupils, colleagues

8. The principle of the operation of the children's home is fairness (within the family - love)

9. The number of pupils in children's homes assumes the necessity of the fair treatment of all

10. The transience of children's home residents and staff, the limited and often diverse and individual purpose of the stay, do not allow the formation of a group subculture 
11. The basic dynamic force in the creation of the common good within the family is love, while in the children's home the "executive norm of the common good" is poorly represented, and in fact belongs to the educators, administration, and management of the home, and reaches the child as "an impersonal, unmotivated compulsion, order, command; sometimes a gift" (Kukołowicz, 1972, pp. 201-202).

Generally speaking, we can note that in the family the common good reveals a greater richness in all its aspects, and it affords a wider opportunity for contact with the common good of other social groups, with the general specific issues of life, and, above all, with love, than is the case in the children's home.

\section{Conclusions}

The human being has both an individual and a social nature, which indicates the necessity of taking into account in the process of the social engagement of the child both care for the child's own development (personalisation) and its orientation towards social life (socialisation), and this in every educational and socially engaging activity. In social engagement there is a justifiable need for both family care and support for the development of the child by the parents and the family, as well as for social (State) care, and the cooperation of these environments should take place without violating the rights of other persons or subjects entitled to upbringing - especially the family.

Thus, the will of children and their parents, and then the social (political, State) goals, needs, and plans related to the upbringing of future generations, should be solved by "cooperation", and in mutual openness to each other. Such "cooperation" in the name of action for the social engagement of the child, although not easy, is possible, and requires learning the art of such action - as we observe, for example, in democracy. The participation and responsibility of parents in the upbringing of children and young people should, by its very nature, be seen as fundamental and primary, and it is the family which provides the best guarantee of the satisfactory social engagement of the child, especially by relating the aims of this activity to the common good. 
Within the school and other care and educational institutions, with varying degrees of competence and responsibility, there should be a wider emergence of genuine cooperation between children, young people, families, parents, educators, social, and State and Church institutions and organisations. For such cooperation, a partnership in the broadest sense of the term would be particularly advisable, with genuine "dialogue" as the means. 


\section{REFERENCES}

Ackerman, N. W. (1959). The Psychodynamics of Family Life. Diagnosis and Treatment of Family Relationships., New York: Basic Books, Inc.

Adamski, F. (2002). Rodzina. Wymiar społeczno-kulturowy [Family. The socio-cultural dimension]. Kraków: Wydawnictwo UJ.

Allport, G. W. (1988). Osobowość i religia [Personality and religion], Warsaw: PAX.

Bartnicka, K. (2014). Komisja Edukacji Narodowej i jej "Ustawy" [Committee of National Education and its "Laws"]. In: K. Dormus, B. Popiołek, A. Chłosty-Sikorskiej, R. Ślęczki (ed.), Komisja Edukacji Narodowej : kontekst historyczno-pedagogiczny (pp. 109-132). Kraków: Wydawnictwo Wydziału Pedagogicznego Uniwersytetu Pedagogicznego im. Komisji Edukacji Narodowej.

Bartnicka, K. (1998). Wychowanie patriotyczne w szkołach Komisji Edukacji Narodowej [Patriotic education in schools of the Committee of National Education]. Warszawa: Żak - Wydawnictwo Edukacyjne Zofii Dobkowskiej

Bauman, Z. (1994). Moralne obowiązki, etyczne zasady [Moral responsibilities, ethical principles]. Etyka 27, pp. 9-28.

Bauman, Z. (2008). Wszystko, co stałe, wyparowało [Everything solid has evaporated]. [In] Idee z pierwszej ręki: antologia najważniejszych tekstów "Europy" - sobotniego dodatku do "Dziennika". Wybór tekstów [First-hand ideas: an anthology of the most important texts of "Europa", the Saturday supplement to "Dziennik". A selection of texts] (pp. 121-142). C. Michalski, M. Nowicki. Warsaw: Axel Springer Polska.

Bednarik, K. (1954). Die Lerngesellschaft [The Learning Society]. Wien-München: Molder.

Crisp, R. J., Turner, Rh.N. (2009). Psychologia społeczna [Social psychology]. Warsaw: PWN. Czachorowski, M. (2020). Personalistyczna etyka Karola Wojtyły wobec zarzutów współczesnego antypersonalizmu [Karol Wojtyła's personalist ethics in the face of charges of contemporary anti-personalism]. Logos i Ethos. Kraków, 1 (53), pp. 97-117.

Foucault, M. (1994). The Essential Works of Michel Foucault 1954-1984, vol. 1: Ethics: Subjectivity and Truth. New York: Ed. P. Rabinow.

Han-Ilgiewicz, N. (1970). Prawidłowy i nieprawidłowy układ stosunków $w$ rodzinie [Correct and incorrect relations within the family]. Nowa Szkoła, 5.

Hołub, G. (2013). Od antropologii do etyki postmodernistycznej: w stronę autentyczności czy dowolności? [From anthropology to postmodern ethics: towards authenticity or arbitrariness?]. In B. Stańkowski, M. Szpringer (ed.), W labiryncie wychowania. Wyzwania edukacyjne w ujęciu interdyscyplinarnym [Educational challenges from an interdisciplinary perspective] (pp. 29-44), Kraków: Wydawnictwo Ingnatianum/WAM.

Commission of National Education. (1872). Ustawy Komisji Edukacji Narodowej dla stanu akademickiego i na szkoły w krajach Rzeczypospolitej przepisane: $w$ Warszawie roku 1783 [Laws of the Commission of National Education for academic status and for schools in the countries of the Republic: in Warsaw in the year 1783]. Lwów: Wyd. Stanisław Sobieski. 
Kondziela, J. (1968). Pojęcie „Bonum Commune” na tle współczesnych kierunków etyki katolickiej [The concept of "Bonum Commune" against the background of contemporary trends in Catholic ethics]. Śląskie Studia Historyczno-Teologiczne [Silesian Historical and Theological Studies], T. I., pp. 46-72.

Krucina, J. (1967). Struktura społecznej zasady dobra wspólnego [Structure of the social principle of the common good]. Roczniki Filozoficzne, Issue 2 (Vol. 15), pp. 21-43. Kukołowicz T. (1968), Pojęcie uspołecznienia. Sprawozdania z Czynności Wydawniczej $i$ Posiedzeń Naukowych TN KUL [The concept of social engagement. Reports of Editorial Activities and Scientific Sessions of The Learned Society of the John Paul II Catholic University of Lublin], No. 17.

Kukołowicz, T. (1972). Dobro wspólne w sytuacjach uspołeczniających dziecko w rodzinie [The common good in situations socially engaging the child in the family]. Roczniki Filozoficzne, Issue 2 (Vol. XX), pp. 185-204.

Kukołowicz, T. (1978). Rodzina w procesie uspołecznienia dziecka [The family in the child's social-engagement process], Lublin, Wydawnictwo KUL.

Kukołowicz, T. (1998). O wychowaniu przez codzienność w rodzinie [On education through everyday family life], [in] Id., Rodzina wychowuje. Wybrane zagadnienia [The family educates. Selected issues] (pp. 207-212). Stalowa Wola: Publishing House of the University Foundation in Stalowa Wola.

Kunowski, S. (1993). Podstawy wspótczesnej pedagogiki [The fundamentals of modern pedagogy]. Warsaw: Wydawnictwo Salezjańskie.

Lacroix, J. (1958). La famille et le mouvement des idées. [The family and the movement of ideas] La Famille Aujourd'hui. Paris, 1958, pp. 159-179.

Nowak, M. (1992). Pedagogika adaptacji w społeczności pluralistycznej [The pedagogy of adaptation in a pluralistic community], In B. Suchodolski - I. Wojnar (ed.), Adaptacja - Ucieczka - Twórczość. Materiały na Konferencję PAN - Komitet Prognoz 'Polska w XXI wieku' przy Prezydium PAN [Adaptation - Escape - Creativity. Materials for the Conference of the Polish Academy of Sciences - ,Poland in the XXI Century' Forecast Committee at the Praesidium of the Polish Academy of Sciences] (pp. 1-27), Jachranka: Polish Academy of Sciences (November).

Nowak, M. (1993). Główne nurty wspótczesnej filozofii wychowania. Kultura i Edukacja [The main trends in the contemporary philosophy of upbringing. Culture and Education.] Toruń, 2 (4), pp. 8 - 27.

Nowak, M. (1999). Podstawy pedagogiki otwartej [The basics of open pedagogy]. Lublin: RW KUL.

Nowak, M. (2008). Teorie i koncepcje wychowania [Theories and concepts of upbringing]. Warsaw: WAiP.

Nowak, M. (2009). Podmiotowość - jej znaczenie i wartość w pedagogice chrześcijańskiej [Subjectivity - its meaning and value in Christian pedagogy]. Paedagogia Christiana. Toruń: UMK, 2 (24), pp 11-23. 
Nowak, M. (2010). Doświadczenie dialogu w tworzeniu wiedzy pedagogicznej [The experience of dialogue in the development of pedagogical knowledge]. In: E. Dąbrowa, D. Jankowska (ed.), Pedagogika dialogu w rzeczywistości XXI wieku [The pedagogy of dialogue in the reality of the 21st century] (pp.168-182). Warsaw: Maria Grzegorzewska University Press.

Nowak, M. (2017). Godność osoby ludzkiej i jej implikacje pedagogiczne [Dignity of the human being and its pedagogical implications]. In N. Rykowska, T. L. Kuniszewska (MSF), R. Stopikowski (ed.), Wśród swoich. Ksiądz Profesor Edward Walewander [Among one's own. Fr. Professor Edward Walewander] (pp. 299-308). Lublin: The Learned Society of the John Paul II Catholic University of Lublin.

Pestalozzi, J. H. (1955). Jak Gertruda uczy swoje dzieci [How Gertrude teaches her children]. Wrocław: Ossolineum.

Rorty, R. (1996). Przygodność, ironia i solidarność [Contingency, Irony, and Solidarity], translated by W. J. Popowski. Warsaw: Spacja.

Rorty, R. (1997). Pragmatyzm i filozofia post-nietzscheańska [Pragmatism and post-Nietzschean philosophy]. In R. Nycz (ed.), Postmodernizm. Antologia przekładów [Postmodernism. An anthology of translations] (43-56). Kraków: Wydawnictwo Baran i Suszczyński.

Schaffer, H. R. (2005). Psychologia dziecka [Introducing child psychology]. Warsaw: PWN.

Skorupka, S., Auderska, H., Łempicka, Z. (ed.) (1969), Mały słownik języka polskiego [A small dictionary of Polish]. Warsaw: PWN, 1969.

Stownik języka polskiego PWN [A small PWN dictionary of Polish], [in] https://sjp. pwn.pl (accessed on 15 April 2021).

Szczepański, J. (1970). Elementarne pojęcia socjologii [The elementary concepts of sociology]. Warsaw: PWN.

Tartler, R. (1955). Das Anpassungsziel wird die permanente Anpassung selbst [The adaptation goal will be the permanent adaptation itself] In $\mathrm{H}$. Schelsky (Hrsg.), Arbaiterjugend gestern und heute (pp. 331-342), Heidelberg: Verlag Quelle \& Meyer.

Wojtyła, K. (1979). Promieniowanie ojcostwa [The Radiance of Fatherhood], [in] Idem. Poezje i dramaty [Poetry and Dramas] (pp. 228-258). Kraków: Znak 1979.

\section{ENDNOTES}

[1] A collection of documents published in 1783 in Warsaw: Commission of National Education, Ustawy Komisji Edukacji Narodowej dla stanu akademickiego i na szkoły w krajach Rzeczypospolitej przepisane [Acts of the Commission of National Education prescribed for the academic status and for schools in the countries of the Republic], constituted a code of school law, and one of the most-important documents issued by the Commission, regulating all educational issues and the educational system. 